\title{
Relief of severe left ventricular outflow obstruction in a case of hypertrophic obstructive cardiomyopathy treated with practolol
}

\author{
M. El Gamal, G. B. A. Schasfoort, and L. C. M. Schrijvers \\ From the Department of Cardiology, Catherina Ziekenhuis, Eindhoven, The Netherlands
}

\begin{abstract}
The clinical and haemodynamic findings in a patient with hypertrophic obstructive cardiomyopathy and severe left ventricular outflow obstruction are presented. Treatment with an increasing dose of orally administered practolol up to a maximum of $1200 \mathrm{mg}$ a day, resulted in symptomatic improvement, and abolition of the resting gradient when the patient was recatheterized six months later.
\end{abstract}

\section{Case report}

A 46-year-old white woman was first seen on 28 Deccember 1972. For the previous 6 months she had experienced attacks of tightening left pectoral pain on exertion, which slowly progressed in severity.

A month before examination she noted breathlessness on exertion and while cycling she suffered from an attack of acute shortness of breath, during which she sweated profusely and was noted to be very pale. On further questioning, she did not suffer from palpitations, dizziness, or fainting attacks. She had no past history of rheumatic fever.

\section{Family history}

She has 2 brothers and 4 sisters in Switzerland, who are in good health as far as she knows. Her father died at the age of 75 ; the cause of death is not known. On examination, the jugular venous pressure was normal, pulse regular, femoral artery pulsations palpable without delay, blood pressure $150 / 90 \mathrm{mmHg}$. On examination of the heart, a double left ventricular impulse was noted in the fifth intercostal space in the midclavicular line. On auscultation there was a loud fourth sound at the apex and over the lower sternal edge, and a grade 3/6 ejection type murmur, loudest between the apex and the lower sternal edge; at the base the murmur was soft (grade I to 2/6), not radiating to the carotid arteries. The second sound was closely split. Further physical examination was uninformative. Chest $x$-ray showed a heart of normal size and configuration (cardiothoracic ratio 13/28.5). The hila and lung fields were normal.

Electrocardiogram (Fig. IA) showed sinus rhythm, $P R$ interval $0.12 \mathrm{sec}$, notched $P$ waves, left ventricular hypertrophy and strain pattern. Phonocardiogram showed prominent fourth sound in the frequency range 35 and $70 \mathrm{~Hz}$. There was an ejection systolic murmur of maximal intensity between the lower sternal edge and the apex; it ended before a closely split second sound. Carotid pulse recording showed a rapid upstroke time $0.05 \mathrm{sec}$ followed by a second rounded wave in late systole. Systolic ejection time $0.30 \mathrm{sec}$. Jugular venous pulsations showed prominent a waves. Apexcardiogram showed large $A$ waves, 20 per cent of the total deflection.

Cardiac catheterization was done on 4 January 1973 (Table, Fig. 2). Right and left heart studies were performed. Left ventricular pressure was measured in the inflow via transseptal catheter; ascending aortic pressure was recorded via a catheter introduced into the right femoral artery by the Seldinger technique. Pertinent haemodynamic data included: left atrial mean pressure $17 \mathbf{m m H g}$, left ventricular systolic pressure $250-280$ $\mathrm{mmHg}$, end-diastolic pressure $23-30 \mathrm{mmHg}$, maximal

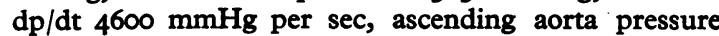
$148 / 68 \mathrm{mmHg}$, peak systolic pressure gradient at rest 132 mmHg, heart rate 114 a minute, cardiac index 3.06 litres $/$ min per $\mathrm{m}^{2}$, stroke index $25.5 \mathrm{ml} / \mathrm{m}^{2}$. Ten minutes after injection of $20 \mathrm{mg}$ practolol intravenously, the left ventricular systolic pressure fell to $208 \mathrm{mmHg}$, aortic systolic pressure was $136 \mathrm{mmHg}$, peak systolic gradient $72 \mathrm{mmHg}$, left ventricular end-diastolic pressure 18 $\mathrm{mmHg}$, heart rate 94 a minute. Left ventricular cineangiogram in the left lateral position showed a small left ventricular cavity with a thickened wall. There was severe obstruction of the outflow of the left ventricle by a hypertrophied locally protruding septum, resulting in a well-defined subaortic chamber. There was grade 3 mitral regurgitation, but there were a number of ventricular extrasystoles during contrast injection in the left ventricle.

Treatment was begun with practolol twice daily, $100 \mathrm{mg}$, and increased to twice daily, $200 \mathrm{mg}$, on discharge (9 January 1973). The case was subsequently discussed at the Cardiothoracic Unit of the Antonius hospital in Utrecht, when it was decided to continue 


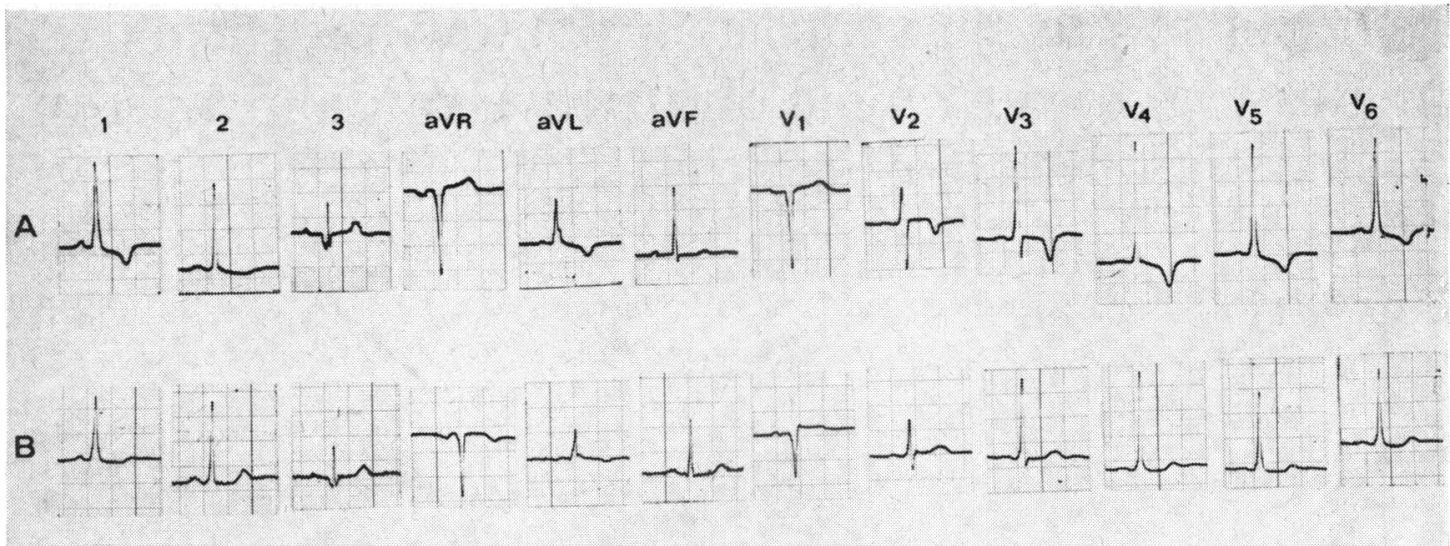

FIG. I Electrocardiograms ( $A$, I fanuary 1973; and $B, 6$ fune 1973) showed considerable improvement in the left ventricular abnormality on 6 fune 1973.
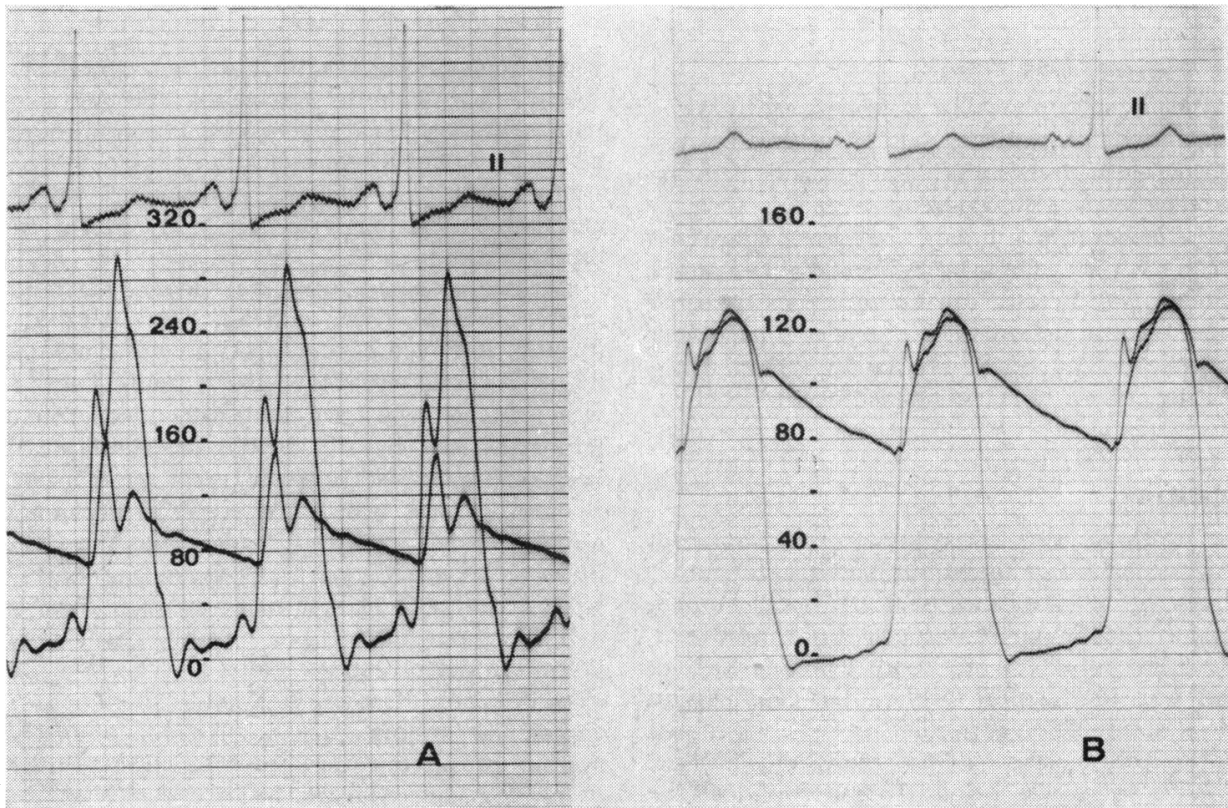

160.

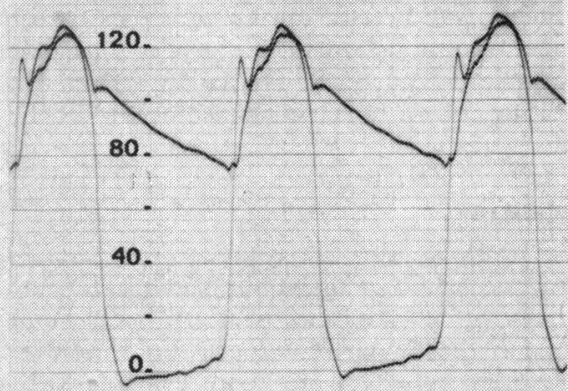

B

FIG. 2 Simultaneous recording of left ventricular inflow and ascending aorta pressure. A) 4 fanuary 1973; B) 7 fune 1973. Loss of left ventricular outflow tract gradient when the patient was reinvestigated on $7 \mathfrak{F}$ une 1973 is shown.

temporarily with beta-blockers in view of the significant reduction in the systolic gradient after intravenous injection.

The dose of practolol was increased at monthly intervals by $200 \mathrm{mg}$, up to a maximum daily dosage of $1200 \mathrm{mg}$, which she continues to take up to the present time. During the first three months she was advised to take things easily. After three months restrictions on her physical activity were eased because she was feeling well, and on clinical examination there were signs of improvement.

In June 1973 she was admitted to hospital in order to reassess her cardiac status. On examination her venous pressure was normal, pulse 72 a minute regular, blood pressure $140 / 90 \mathrm{mmHg}$. There was no cardiac enlargement; on auscultation there was a grade $2 / 6$ midsystolic 
TABLE Haemodynamic data

\begin{tabular}{|c|c|c|c|c|c|c|c|c|}
\hline & $R V$ & $\begin{array}{l}L A \\
\text { mean }\end{array}$ & $\begin{array}{l}L V \\
\text { S/ed/max } d p / d t\end{array}$ & Ao $S / D$ & $L V-A o$ & $H R / \min$ & $\begin{array}{l}\text { Cardiac index } \\
\left(\text { l./min per } m^{2}\right)\end{array}$ & $\begin{array}{l}\text { Stroke index } \\
\left(\mathrm{ml} / \text { stroke per } m^{2}\right)\end{array}$ \\
\hline \multicolumn{9}{|l|}{4 January 1973} \\
\hline Rest & 46 & 17 & $\begin{array}{l}280,23,4600 \\
\mathrm{mmHg} / \mathrm{sec}\end{array}$ & $148 / 68$ & 132 & II 4 & 3.06 & $25 \cdot 5$ \\
\hline $\begin{array}{l}\text { Io minutes } \\
\text { after practo- } \\
\text { lol } 20 \mathrm{mg} \text { i.v. }\end{array}$ & - & - & 208,18 & $136 / 72$ & 72 & 94 & 一 & - \\
\hline 7 June 1973 & 24 & $2 \cdot 5$ & $\begin{array}{l}\mathrm{I22}, \mathrm{I} \text { I,2200 } \\
\mathrm{mmHg} / \mathrm{sec}\end{array}$ & $122 / 70$ & 0 & 76 & $3 \cdot 44$ & 45 \\
\hline $\begin{array}{l}\text { Exercise } \\
5 \text { minutes } \\
\text { Isoprenaline }\end{array}$ & - & - & I60-176, I5 & $140-152$ & $12-24$ & IIO & $3 \cdot 1$ & 28 \\
\hline $20 \mu \mathrm{g}$ i.v. & - & - & $164,12-14$ & $126 / 68$ & 38 & 76 & 一 & - \\
\hline
\end{tabular}

Abbreviations: $\mathrm{RV}=$ right ventricular pressure $(\mathrm{mmHg})$; LA mean $=$ left atrial mean pressure $(\mathrm{mmHg}) ; \mathrm{LV}=$ left ventricular pressure $(\mathrm{mmHg}), \mathrm{S}=$ systolic, $\mathrm{D}=$ diastolic, ed =end-diastolic; $\mathrm{LV}-\mathrm{Ao}=$ left ventricular-aortic pressure gradient (mmHg); $\mathrm{HR}=$ heart rate per minute.

ejection murmur maximal between the apex and the lower sternal edge. A fourth heart sound was no longer audible.

Electrocardiogram (Fig. I B) indicated sinus rhythm, PR 0.20 sec, inverted $T$ waves in lead aVL, but no further abnormalities. All signs of left ventricular hypertrophy and strain had regressed. Compared to the record of January 1973, the phonocardiogram showed that the midsystolic murmur was shorter in duration and lower in amplitude (identical gain on the pick-up microphone was used during both recordings). The fourth sound was much smaller. The upstroke time of the carotid curve was now longer, $0.08 \mathrm{sec}$, and ejection time was $0.30 \mathrm{sec}$. There was a change in the shape of the carotid pulse tracings; in only occasional recordings was there a small secondary rounded wave in late systole. On the apex cardiogram the $A$ waves were now 13 per cent of the total deflection. On chest $x$-ray the heart remained unchanged in size and shape (cardiothoracic ratio $13 / 28.5$ ). The hila and lung fields were normal. Repeat cardiac catheterization on the 7 June 1973 (Table) revealed a right ventricular systolic pressure of $24 \mathrm{mmHg}$, left atrial mean pressure of $2.5 \mathrm{mmHg}$, left ventricular systolic pressure $122 \mathrm{mmHg}$, end-diastolic pressure I $\mathrm{mmHg}$, maximal dp/dt $2200 \mathrm{mmHg}$ per sec, and ascending aortic pressure $122 / 70 \mathrm{mmHg}$. On simultaneous recording of the left ventricular and ascending aortic pressure at rest, there was no systolic gradient. Pulse rate at rest was 76 a minute, cardiac index $3.441 . / \mathrm{min}$ per $\mathrm{m}^{2}$, and stroke index $45 \mathrm{ml} / \mathrm{m}^{2}$. During exercise (straight leg raising for 5 minutes) the heart rate increased to Iro a minute, cardiac index was $3.1 \mathrm{l} . / \mathrm{min}$ per $\mathrm{m}^{2}$, and the stroke index was $28 \mathrm{ml} / \mathrm{m}^{2}$. Simultaneous recording of left ventricular and ascending aortic pressure after 5 minutes of straight leg raising revealed a systolic gradient that varied between 12 and $24 \mathrm{mmHg}$; the heart rate was 94 a minute. In post-extrasystolic beats the gradient was $60 \mathrm{mmHg}$. Left ventricular end-diastolic pressure during exercise was I5 $\mathrm{mmHg}$. A total dose of $20 \mu \mathrm{g}$ isoprenaline was intravenously injected without any acceleration of the heart rate; however, a systolic gradient of $38 \mathrm{mmHg}$ developed. Left ventricular cineangiography was repeated in the left lateral position, and there was no change in the appearance of the left ventricle and outflow tract when compared with the angiogram of January 1973.

The patient was discharged, and treatment was continued with $1200 \mathrm{mg}$ practolol daily. She was last seen at the outpatients' department on 4 December 1973, when she reported that she was feeling well, with no shortness of breath, and no effort angina. The patient sometimes experiences a mild sensation of pressure in the left pectoral region, but always unrelated to exertion. The only side effects from practolol therapy have been constipation and nightmares, but the latter have not been troublesome lately. The patient continues to take practolol in the same dosage (1200 $\mathrm{mg}$ a day) and is being followed up at 3-monthly intervals.

\section{Discussion}

The published work on practolol up to date in patients with hypertrophic obstructive cardiomyopathy has shown no significant effect on outflow tract obstruction at rest or with stress (WebbPeploe, Croxson, and Oakley I971a; Matlof and Harrison, 1973) but left ventricular end-diastolic pressure was lowered (Webb-Peploe et al., I971a, b). It is generally accepted that few seriously symptomatic patients with severe outflow tract obstruction can be spared operative treatment by beta-adrenergic blockade.

Contrary to the experience of other workers, practolol $20 \mathrm{mg}$ injected intravenously at the first 
catheterization (4 January 1973) significantly diminished the gradient across the outflow tract of the left ventricle (132 $\mathrm{mmHg}$ before, and $72 \mathrm{mmHg}$ Io minutes after). Encouraged by the result, we continued therapy with orally administered practolol in increasing doses up to a maximum of $1200 \mathrm{mg}$ daily. Six months later there were subjective and objective signs of improvement, and when recatheterized the resting gradient across the outflow tract of the left ventricle was abolished.

Further trial of long-term practolol therapy in cases of hypertrophic obstructive cardiomyopathy and severe outflow tract obstruction seems justified.

We wish to thank Mr. L. M. van Gelder for his tech- nical assistance, and Mr. G. W. Melman (I.C.I. Holland) for his helpful advice.

\section{References}

Matlof, H. J., and Harrison, D. C. (1973). Acute haemodynamic effects of practolol in patients with idiopathic hypertrophic subaortic stenosis. British Heart fournal, 35, 152.

Webb-Peploe, M., Croxson, R. S., and Oakley, C. M. (I97Ia). Beta-adrenergic blockade with practolol in hypertrophic obstructive cardiomyopathy (abstract). British Heart Fournal, 33, 143.

Webb-Peploe, M. M., Croxson, R. S., Oakley, C. M., and Goodwin, J. F. (I97Ib). Cardioselective beta-adrenergic blockade in hypertrophic obstructive cardiomyopathy. Postgraduate Medical fournal, 47, January Suppl., 93.

Requests for reprints to Dr. M. El Gamal, Department of Cardiology, Catharina Ziekenhuis, Eindhoven, The Netherlands. 